\title{
Bakke in Balance: Some Preliminary Thoughts
}

\author{
Robert M. O’Neil†
}

The Bakke decision ${ }^{1}$ was a long time in coming, and one may well wonder whether it was worth the wait. The Supreme Court has now given some guidance with respect to the role of race in higher education, although at least as many questions have been raised as have been answered. The Court has already agreed to review several related cases this term, ${ }^{2}$ indicating a willingness to provide further answers. Meanwhile, college and university administrators across the country must do the best they can with the modest guidance that the Bakke opinions afford. ${ }^{3}$ This Article seeks to aid the process of understanding Bakke, fully conscious of the risks of extrapolation at this early stage.

Several propositions emerge from the opinions and may provide a starting point for legal analysis. First, no member of the Court foreclosed the use of race in higher education. Five Justices clearly held that the California Supreme Court erred in forbidding race-conscious admissions policies. ${ }^{4}$ The other four Justices did not speak to the issue and, indeed, warned those who might be tempted to find in their opinion any indication of a broader judgment not to do so. They expressly reserved the constitutional issue of the role of race for a later case ${ }^{5}$ and addressed only the legahity of the single admissions program before the

$\dagger$ Vice President at Bloomington and Professor of Law, Indiana University. A.B. 1956, A.M. 1957, LL.B. 1961, Harvard University.

1. Regents of the University of California v. Bakke, 98 S. Ct. 2733 (1978).

2. See, e.g., County of Los Angeles v. Davis, 566 F.2d 1334 (9th Cir. 1977), cert. granted, 98 S. Ct. 3087 (1978) (No. 77-1553); Kaiser Aluunimum and Chem. Corp. v. Weber, 563 F.2d 216 (5th Cir. 1977), cert. granted, 47 U.S.L.W. 3401 (Dec. 11, 1978) (No. 78-435); Cannon v. University of Chicago, 559 F.2d 1077 (7th Cir. 1977), cert. granted, 98 S. Ct. 3142 (1978) (No. 77-926). See also N.Y. Times, July 4, 1978, at 1 , col. 6 .

3. ACE-AALS Committee on Bakke, The Bakke Decision: implications for Higher Education Admissions (W. McCormack ed. 1978).

4. Bakke v. Regents of the Univ. of Cal., 18 Cal. 3d 34, 553 P.2d 1152, 132 Cal. Rptr. 680 (1976), aff' in part, rev'd in part, 98 S. Ct. 2733 (1978).

5. Regents of Univ. of Cal. v. Bakke, $98 \mathrm{~S}$. Ct. at 2810 (opinion of Stevens, J.).

It is also arguable, though less clear, that the Stevens group wished to reserve the statutory issue as well as the constitutional issue. Although language im the opimion might imply a broader disfavor toward any preferential use of race as a Title VI matter, other language suggests that the Stevens group desired to keep open all issues, both statutory and constitutional, other than the precise factual issue before the Court in Bakke. Id. 
Court. It is most significant that no Justice disapproved the use of race on constitutional grounds.

Second, at least five Justices presumably would sustain some type of race-conscious admissions program, like the Harvard College program to which Justice Powell referred with clear approval. ${ }^{6}$ There is, however, a hint that Justices Brennan, White, Marshall, and Blackmun would require some showing of past discrimination against the groups favored by such a prograin, and would need to be convinced that such a prograin would not stiginatize those groups. ${ }^{7}$ Curiously, Justice Powell may have been readier to uphold certain race-conscious programs than were the four other Justices who approved even the Davis prograin. An obvious warning einerges: In designing any race-conscious policy to capture a majority of the present Court, one must be careful not to lose any of the Brennan group in the course of seeking Justice Powell's approval.

Third, a bare majority of the Court did strike down the Davis admissions program, although on different grounds. It is uncertain what factual variations might shift the vote of one nember of that tenuous inajority. Simply altering the number of places reserved for minority applicants from sixteen to fifteen or seventeen obviously would not alter the result. But relatively subtle changes in the process by which applications were reviewed, or in the resulting minority representation, could well produce a different alignınent.

In extrapolating from these propositions, we must be mindful of the peculiar factual context of the Bakke case. Neither the Harvard nor the Davis program is representative of the spectrum of admissions policies used today by institutions of higher education. The Davis prograin was extraordinary in the high degree to which it employed race as a criterion of admission. The Harvard program is quite distmctive in other ways. ${ }^{8}$ While many institutions of higher learning must be selective, their applicant pools seldom contain the richness and variety of the group of high scliool seniors who seek admission to Harvard College. The simple fact is that most admissions policies are quite unlike either the Harvard or the Davis program, and their validity thus must be judged by analogy.

In addition, the principles enunciated in Bakke will have effect throughout the field of higher education. Although the Supreme Court

6. The program was described in Brief of Columbia University, Harvard University, Stanford University, and the University of Pennsylvania, as Amici Curiae.

7. $98 \mathrm{~S}$. Ct. at 2785.

8. Justice Powell also referred to statements of the President of Princeton University re-4, garding that institution's undergraduate admissions philosophy. Id. at 2760 n.48. Princeton shares with Harvard distinctive qualities that limit the applicability of its admissions policies to other institutions of higher learning. 
properly said nothing about the issues of recruitment, financial aid, tutorial programs, summer institutes, and other aspects of higher education in which race may play a role, judgments about their legality must now be made on the basis of Bakke. University officials and their lawyers simply will do the best they can with the raw material provided by the opinions and must reason by analogy from admissions to other areas in which the use of race inay be challenged.

It is vital to recognize the limitations inherent in the Supreme Court's first attempt to address the issue of voluntary preferential use of race. ${ }^{9}$ Later cases undoubtedly will challenge the admissions policies of otlier colleges and universities-both those already in place that may seem more vulnerable in light of Bakke, and others that may be adopted or altered in hight of the decision. There is simply no way (absent, of course, preemptive federal legislation under Title VI) to forestall a substantial number of legal challenges to the use of race in higlier education.

Witl these precepts in mind, we should now explore the constitutional import of the opinions. We begin with the central issue of the standards applicable to judging racial classifications. Justice Powell's opinion provides the necessary point of departure.

\section{Justice Powell and the Standard of Justification FOR THE ROLE OF RACE IN ADMISSIONS}

Any analysis of the application of Bakke inust begin with a discussion of the constitutional issue. It is now quite clear-if ever there was much doubt-that racial classifications are not per se invalid. ${ }^{10} \mathrm{Be}-$ yond this point the path is uncertam, since the division of tlie Justices left the Court without a consensus on the appropriate standard for reviewing racial classifications. The four Justices comprising the Brennan group would use a "substantial interest" standard for judging classifications which benefit, rather than disadvantage, racial minorities. The four Justices comprising the Stevens group liad no occasion to adopt any standard. The remaming menber of the Court, Justice Powell, would apply a "strict scrutiny" standard, requiring that beneficial and detrimental racial classifications alike be shown to be necessary to

9. DeFunis v. Odegaard, 416 U.S. 312 (1974), would, of course, have been the first such case had the lower-court decision not been dismissed as moot. See generally Sympo. sium-DeFunis: The Road Not Taken, 60 VA. L. REv. 917 (1974); DeFunis Symposium, 75 Colum. L. REv. 483 (1975).

10. For a discussion of this issue, raising doubts about whether a per se test might eventually be invoked, see O'Neil, Preferential Admissions: Equalizing the Access of Minority Groups to Higher Education, 80 YALE L.J. 699, 707-09 (1971). 
a "compelling" governmental interest."

Justice Powell's opinion is, of course, critical in evaluating the constitutional issue. Four of his colleagues were willing to sustain even the Davis program, and the other four would not go beyond striking it down on the narrowest possible ground. Thus, on the basis of the opinions in Bakke, Justice Powell's vote seeins essential for a inajority of the court to sustain or to invalidate any particular race conscious admissions program. Given the strategic importance of his vote and because he was the only inember of the Court to discuss admissions systcins cinploying racial preferences that would and would not pass muster under the fourteenth annendment, Justice Powell's opinion assumes an oracular quality. By focusing on Justice Powell's opinion and exploring incidentally the opinions of the other Justices, this Article will discuss the guidance provided educators in Bakke. ${ }^{12}$

Justice Powell's view of the constitutional standard is the traditional, cautious view; he rejects the possibility of a dual standard and insists upon "strict scrutiny" regardless of the group being favored or disfavored by the classification. There is much scholarly support for this view, developed clsewhcre ${ }^{13}$ and partially summarized in the Powell opmion. ${ }^{14}$ The use of race is inherently divisive, whichever way the classification cuts. Achieving equality by using racial classifications beneficial to minorities may undermine the authority of a governunent committed to climinating inequality. Determining what constitutes a "minority" for the purpose of preference or inclusion is a complex and sensitivc task. The process of separating bencficial from detrimental classifications might well involve the Court in sociological and political questions beyond its institutional competence. The case against the dual standard is a persuasive one. The wonder, therefore, is not that

11. $98 \mathrm{~S}$. Ct. at 2756-57. The language Justice Powell used to describe the "strict serutiny" test was not consistent. At points in his opinion, he characterized interests that would satisfy his standard as "compelling." Id at 2753, 2758. At other points, he described such interests as "legitimate and substantial," or as "constitutionally permissible." Id. at 2757.

12. The importance of Justice Powell's views can easily be exaggerated. On the one hand, it is quite possible that a member of the Stevens group in a later case might reach the constitutional issue and resolve it in favor of a plan differing only slightly from the Davis program. On the other hand, one or more inembers of the Breman group might be less favorably disposed to other programs-because of either the absence of past discrimination or the presence of a stigma-and would thus join the nay sayers. Neither the Stevens group nor the Brennan group is monolithic, as we know from other cases in which the Court has been less cohesive than it was in Bakke. See, e.g., United Jewish Organizations, Inc. v. Carey, 430 U.S. 144 (1977). Should such a shift occur, Justice Powell's opmion would lose much of its importance. See Dworkin, The Bakke Decision: Did it Decide Anything?, N.Y. Rev. of Books 20 (Aug. 17, 1978). For the moment, however, Justice Powell's opinion seeins to warrant the attention it has already received. See, e.g., Wicker, The "Powell Test," N.Y. Times, July 21, 1978, § A, at 1, col. 5-6.

13. See, e.g., Graglia, Special Admission of the "Culturally Deprived" to Law School, 119 U. PA. L. Rev. 351 (1970); Kaplan, Equal Justice in an Unequal World: Equality for the Negro-the Problem of Special Treatment, 61 Nw. U. L. Rev. 363, 375-78 (1966).

14. $98 \mathrm{~S}$. Ct. at $2751-53$. 
Justice Powell favored a single standard for all racial classifications. The wonder is that he was alone in doing so.

The Brennan group could have provided a inajority for a single standard by choosing to sustain the Davis program following Powell's analysis. It would not have been difficult or dismgenuous to have vahdated the Davis program by finding its racial classifications necessary to a coinpelling interest-much as the Washington Supreme Court did in the DeFunis case. ${ }^{15}$ Instead, the Brennan group chose to ineasure benign racial classifications by the standard used for classifications based on gender. ${ }^{16}$ Simce the ineaning of this intermediate standard is unsettled even in the gender discrimination cases, its extension to race cases introduces new uncertaimty. ${ }^{17}$

\section{II}

\section{The Powell Standard Examined: Unanswered QUESTIONS}

Justice Powell's view of the constitutional standard is clearly enough stated, but its implications are less certain. This lack of clarity stems in large part from Justice Powell's failure either to set forth criteria for identifying compelling imterests or, alternatively, to evaluate the full range of potentially compelling interests. In the absence of such guidance, we must look to the somewhat less than explicit passages of the Powell opinion to discern its possible implications.

Justice Powell's treatment of earlier equal protection cases that upheld racial classifications favoring minorities is characteristic of his ambiguous handling of the concept of compelling governmental imterest. In reviewing cases such as Lau v. Nichols, ${ }^{18}$ United Jewish Organizations, Inc. v. Carey, ${ }^{19}$ and the school segregation cases, ${ }^{20}$ Justice Powell found that they did not commit the Court to a more lenient standard of review for classifications favoring minorities. Unlike Bakke, said Justice Powell, these cases involved a judicial, legislative, or administrative finding of past discrimination. ${ }^{21}$ Apart froin the question of whether United Jewish Organizations conforms to this characterization, ${ }^{22}$ a central constitutional question went unanswered. It is not clear whether

15. DeFunis v. Odegaard, 82 Wash. 2d 11, 32, 507 P.2d 1169, 1182 (1973), vacated as moot, 416 U.S. 312 (1974).

16. $98 \mathrm{~S}$. Ct. at 2783-84. See Craig v. Boren, 429 U.S. 190, 197 (1976) ("classifications by gender must serve important government objectives and must be substantially related to the achievement of those objectives").

17. See, e.g., Gimsburg, Gender and the Constitution, 44 U. CIN. L. REv. 1 (1975).

18. 414 U.S. 563 (1974).

19. 430 U.S. 144 (1977).

20. E.g., Swann v. Charlotte-Mecklenburg Bd. of Educ., 402 U.S. 1 (1971).

21. $98 \mathrm{~S}$. Ct. at 2756 .

22. Compare Justice Brennan's comments about United Jewish Organizations. Id. at 2781. 
Justice Powell felt that in each of these cases the discriminatory history warranted a lower standard of review and that a lower standard was actually used, or that these cases presented concededly racial elassifications which nonetheless met the strict scrutiny test. The latter theory seems preferable, since Justice Powell rejected the University's claim that the school, employment, and votimg cases supported a double standard in the racial area. ${ }^{23}$ Yet he did not, as one might have expected, offer compelling interests to reconcile the results with the strict standard of review. If such coinpelling interests indeed were present in these cases, then by failing to identify them Justice Powell omitted a critical element in his analysis. If, on the other hand, such interests were not present, then Justice Powell failed to provide a rationale for the validity of the racial classifications in the cases he treated. Perhaps a finding of past discrimination is per se a compelling interest, although Justice Powell did not say so. Had he pursued the issue, he then would have faced the further question of why one's own past discrimination generates a compelling interest, while someone else's past discrimination does not-a quandary obviated under the Brennan group's fornulation.

When Justice Powell did explicitly identify an interest as coinpelling, he left it unclear precisely why the identified interest had achieved this status. In labeling the goal of diversity as compelling, for example, he emphasized the principle of academic freedoin, which he derived froin the first amendment, but provided no other guidance. ${ }^{24}$ Similarly, in assessing the validity of the goal of improving the delivery of health care to currently underserved communities, Justice Powell merely stated that "[i]t may be assumed that a State's interest in facihtating the health care of its citizens is sufficiently compelling to support the use of a suspect classification."25 Apparently a compelling intercst need not be rooted in the Constitution; beyond this it is difficult to speculate.

To be quite fair, Justice Powell should not bear alone the blame for this confusion of standards. The compelling interest test in fact derives from opinions in which the Court was more closely in accordstriking down, for example, miscenegation laws ${ }^{26}$ and welfare restrictions. ${ }^{27}$ In no sucl case does there appear to have been developed a clear fornula for identifying an interest as compelling. The Court simply has concluded that various clainied interests would not survive strict scrutiny. If additional interests are to be recognized in the future as compelling, we need to understand the rationale behind labeling an

\footnotetext{
23. Id. at $2747-49$.

24. Id. at 2760 .

25. Id. at 2759.

26. Loving v. Virginia, 388 U.S. 1 (1967).

27. Shapiro v. Thompson, 394 U.S. 618 (1969).
} 
interest "coinpelling." The background and history of the test may have deprived it of the underpinning that it badly needs, but Justice Powell did little to dispel the obscurity that has characterized the use of the strict scrutiny test.

There was an analogous break in the Brennan group's analysis. The rationale for judging certain racial classifications by a standard lower than "strict serutiny" was partially developed. How to draw the line in any given case to determine the applicable standard, however, reinained obscure. Two statements hinted at the basis of distinction. In one passage, the Brennan group indicated that whites do not constitute a suspect class because such a grouping does "not have any of the indicia of suspectness," ${ }^{28}$ such as vulnerability to stiginatization. At another point, they stated that a more lenient approacl is appropriate for "racial classifications designed to further remedial purposes "29 Perhaps, on the facts of Bakke, it is easy enough to locate the line. Other cases can be imagined-a line favoring certain minorities to the detriment of others, for example-im whicl the determination would be much more difficult. Thus, for the Brennan group as for Justice Powell, we know the terms of the resulting standard, but we lack vital insight into the process by which that standard was framed.

Not only did Justice Powell disappoint us by failing to catalogue all of the possibly extenuating interests; in addition, his opinion failed to analyze in sufficient deptli some of the interests actually presented in the case. The University of Califorma did not, of course, advance every imaginable argument in support of race-conscious admission policies. Several of the interests it did offer received rather suminary disposition, essentially for factual rather than legal reasons. Consequently, we do not know what Justice Powell would say about a fully developed "role inodel" arguinent-the claim that increased minority representation in graduate and professional student bodies is a key motivational factor for younger minority students. ${ }^{30}$ Nor do we know how Justice Powell would have appraised a professional admission program designed to offset the exclusionary effects of standardized

28. $98 \mathrm{~S}$. Ct. at 2783.

29. Id. at 2784.

30. The argument has been developed elsewhere. See, e.g., Sandalow, Racial Preferences in Higher Education: Political Responsibility and the Judicial Role, 42 U. CHI. L. REv. 653, 688-89 (1975). Its status in the Powell opinion was uncertain because it was relegated to rather uncongenial company in a footnote dealing with "compensatory" justification for race-conscious admission policies. The most persuasive basis for the "role model" argument, as Professor Sandalow and others advancing it have shown, has little to do with majority guilt or compensation for past exclusion of minorities. The argument would apply equally to other groups such as Vietnamese and Cubans, who are simply underrepresented in American society to their detriment even though they are not the victims of a history of discrimination comparable to that which blacks have suffered. For this reason, Justice Powell's views on the "role model" issue remain unclear. See 98 S. Ct. at 2757 n.43. 
tests and other numerical predictors. ${ }^{31}$ We do know that Justice Powell might accept the underserved areas argument as "compelling"- that is, he might accept a well-documented claim that race must be taken into account in admissions decisions to meet the needs of regions acutely in need of medical care. Since the University failed to argue that the Davis admissions program was necessary or even designed to achieve this goal, Justice Powell refused to rule on this issue. ${ }^{32}$ Justice Powell cannot fairly be faulted for failing to discuss these possible interests more fully-at least to the extent his characterization of the record is accurate. They remain to be heard when they are properly before the Court, and interim speculation about their status would be hazardous.

\section{III}

\section{The Powell Standard Applied: Interests That Justify the Use of RaCial Classifications}

Justice Powell reviewed on their merits four proposed purposes of the use of race in admissions. The first was the prospect that a University might seek "to assure withm its student body some specified percentage of a particular group inerely because of its race or ethnic origin." 33 Such a goal, said Justice Powell, is "facially invalid." 34 "Preferring members of any one group for no reason other than race or ethnic origin is discrimmation for its own sake."35 It is difficult to imagine an admissions policy with so simplistic a goal. Colleges and universities have seldoin adopted race-conscious programs merely because they liked or sympathized with minority groups. This first purpose is really a straw argument, a hypothetical issue included in the list for the sake of completeness.

Another proposed purpose, improving delivery of health care services to underserved communities, essentially was dismissed, as indicated previously, for failure of proof. ${ }^{36}$ Justice Powell admitted that such an interest could be "sufficiently coinpelling to support the use of a suspect classification," ${ }^{37}$ but noted that the University of California had failed to demonstrate any significant relation, much less a necessary one, between its use of race and this objective.

It is the two remaining purposes which deserve considerable atten-

31. See $98 \mathrm{~S}$. Ct. at 2757 n.43. For a discussion of the "numerical predictors" argument, see R. O'Nell, Discriminating Against Discrimination 99-106 (1975), and O'Neil, supra note 10, at $731-37$.

32. $98 \mathrm{~S}$. Ct. at $2759-60$.

33. Id. at 2757.

34. Id.

35. Id.

36. Id. at 2759-60.

37. Id. at 2759. 
tion. One was the goal of eliminating the effects of past discrimination; the other, the desire to achieve diversity in the student body.

\section{A. Eliminating the Effects of Past Discrimination.}

For Justice Powell, there was no doubt that "the State . . . has a legitimate and substantial interest in ameliorating, or eliminating where feasible, the disabling effects of identified discrimination."38 The Brennan group shared this view. While the Brennan group would permit an institution to nnitigate the burdens of discrimination for which it had not been directly responsible, ${ }^{39}$ Justice Powell insisted that inere "societal" discrimination could not be reached. In his view, it seems that only the entity whicl caused the problem may solve it. Even though otlier institutions might have the desire and the capacity to lielp, their interest in doing so would not be "compelling". 40

In addition to past discrimination in fact, Justice Powell would require findings by an appropriate body of both (1) discrimination in the form of constitutional or statutory violations, and (2) responsiveness of the proposed classification to the identified discrimination. The University of California did not purport to have made sucl findings. Moreover, the University "is in no position" to make them. According to Justice Powell, the "broad mission" of a umiversity is "education, not the formulation of any legislative policy or the adjudication of particular claims of illegality." 41 Presumably it would liave made no difference if the Regents of the University of California liad gone through an elaborate procedure (which admittedly they did not) leading them to the conclusion that their admission policies were discriminatory in the past, and that the program adopted by the Davis inedical faculty was an appropriate remedy. Several questions are tlius presented: (1) Why does Justice Powell distrust the Regents to make sucl findings? (2) Who inay make them in lieu of the Regents? (3) What must such findings contain?

\section{Why Distrust the Regents?}

Justice Powell must have had good reasons for feeling that a university governing board is less trustworthy than are courts, legislatures, and other administrative agencies to assess whether a school had unlawfully discriminated in the past. To say that the business of a university governing board is education and not adjudication is correct; but that distinction inerely states a conclusion without justifying it. There must be inore to the issue than appears in Justice Powell's words.

38. Id.

39. Id. at 2789.

40. Id. at 2759.

41. Id. at 2758 . 
In part the concern seemed to relate to process. Courts and some administrative agencies can adjudicate possible statutory and constitutional violations and consequently can measure with some accuracy the extent of legal injury. Furthermore, these mstitutions, along with legislatures, have "the authority and the capabihty to establish, in the record, that the classification is responsive to identified discrimination."42 The procedures of courts and administrative agencies are more formal, their findings more visible, and their decisions more readily subject to review than those of university trustees (at least as Justice Powell perceives the workings of such trustees)..$^{43}$ Thus, any of the mstitutions mentioned will define with greater precision than would a body such as the Uinversity of California Regents the scope and duration of a remedy as well as providing continued monitoring "to assure that it [the reinedy] will work the least possible harm to other innocent persons coinpetimg for the benefit." 44 Justice Powell saw the Regents as lacking these capabilities. To support his view, he pointed to the absence of the kind of record about the Davis program that a more formal process would have produced. Justice Powell stated that, lacking such a record, one could not readily find answers ${ }^{45}$ to such questions as wliy the Davis program included certam ininorities but not others.

Justice Powell also seemed to approve of legislative findings of discrimination and appropriate remedies for more substantive reasons. A legislative body can be trusted inore fully than can the Regents to take into account the competing clainis of all groups seeking a preference. Accountability to the electorate is inore readily assured: "Isolated seginents of our vast governmental structure are not competent to make those decisions, at least in the absence of legislative mandate and legislatively inandated criteria." 46 Justice Powell seemed to believe that the political process could be trusted to allocate scarce resources among competing claimants in ways that university trustees could not be trusted to do. ${ }^{47}$

Finally, there was a hint in Justice Powell's discussion that university governing boards may be tempted to respond expediently to short term or local pressures, while legislatures and statewide administrative bodies inust reflect broader and more durable considerations. He justi-

42. $98 \mathrm{~S}$. Ct. at 2759.

43. See notes 55-56 and accompanying text infra.

44. $98 \mathrm{~S}$. Ct. at 2758.

45. Id. at $2759 \mathrm{n} .45$. Even the brief for the United States, though generally sympathetic to the goals of the Davis program, expressed some puzzlennent about the determination of eligible minorities. Brief for the United States as Amicus Curiae at $71 \mathrm{n} .82$.

46. Id. at 2758-59 (footnote omitted).

47. Professor Sandalow has developed more fully the philosophical basis of the argument about allocation of responsibility for the making of such decisions-particularly the proper role of the political process. See Sandalow, supra note 30, at 693-702. 
fied his opinion by stating that "[t]o hold otherwise would be to convert a remedy heretofore reserved for violations of legal rights into a privilege that all institutions throughout the Nation could grant at their pleasure to whatever groups are perceived as victims of societal discrimination." 48

In short, preferential admission to medical school may siniply be too iniportant a benefit to be the subject of racial preference without an independent vahdation of the foundation for and extent of the preference granted. Groups that can provide such a foundation are characterized by formality of process, political accountability, and insulation from untoward influence by parochial pressures. The University of California Regents, in Justice Powell's view, lack these quahties.

\section{Who May be Trusted if the Regents May Not?}

Justice Powell spoke of "judicial, legislative or administrative findings" of a violation for which race-conscious remedies would be appropriate. $^{49}$ The scope of this pronouncement requires interpretation. Clearly, Justice Powell would accept the holding of a court regarding past discrimination. Thus there seeins to be little doubt about the vahidity of race-conscious admission pohicies at colleges and universities, including many of the state supported institutions in the southeast, that were once ordered to desegregate. ${ }^{50}$ While comparable findings of past segregation are unlikely in other parts of the country, they do provide a starting point.

Other institutions covered by Justice Powell's formula include legislative bodies. An act of Congress would seem to satisfy not only Justice Powell, but also the Stevens group. Presumably, since Congress enacted Title VI, Congress also nnay inodify its scope, implicitly as well as explicitly, by authorizing race-conscious programs in federally assisted institutions of higher learnings. The Stevens group might still find such an action unconstitutional by reaching the issue they felt no need to reach in Bakke. But it is unlikely that every member of the Stevens group would find Title VI more restrictive in regard to preferential policies than is the fourteenth amendment. The concurrence of the Brennan group, however, cannot automatically be assumed in such a case. They might insist, even in reviewing an act of Congress, that the beneficiary group be shown to have suffered discrimination to which the reinedy is reasonably related and that the program not be stigmatizing. By one route or another, though, it should be possible to

48. $98 \mathrm{~S}$. Ct. at 2759.

49. Id. at 2758 .

50. See, e.g., McLaurin v. Oklahoma State Regents, 339 U.S. 637 (1950); Sweatt v. Painter, 339 U.S. 629 (1950); Missouri ex rel. Gaines v. Canada, 305 U.S. 337 (1938). 
garner five votes in favor of nearly any race-conscious remedy expressly sanctioned by Congress.

The acceptabihty of state legislative actions is less clear. We have no idea how the Stevens group would respond. The Brennan group presumably would find state laws relevant though not necessary and would apply tests no more stringent than those applied to the university's action in Bakke. The puzzle, again, is Justice Powell. While he cited witl approval no cases involving a state created racial classification, the rationale behind his fornula clearly implies a degree of deference to sucli actions. The legislature is responsive to the needs of the whole state and is accountable to those who may be omitted from or burdened by the classification. Even though state legislatures frequently operate in a less formal manner than adjudicatory bodies, or even tlian Congress, it seems likely that the degree of procedural formality required for such a judgment would dimimish as the measure of political accountability and authority mcreased. The state legislature is empowered to make sensitive determinations such as those involved $\mathrm{m}$ grantimg remedial preferences. Thus, state legislation would appear to be as satisfactory to Justice Powell as congressional action.

Justice Powell indicated that he would also accept "administrative findings." Presumably an order of a state antidiscrimination or civil rights commission (and a fortiori that of a comparable federal agency) would suffice. Even an order promulgated im response to an imdividual complaint or petition would provide relevant evidence of discrimination which nnight be a proper object of institutional remediation. Both the formality of process and the consonance of jurisdiction and unission would accompany such an administrative proceeding. Moreover, it is the function of such agencies to "adjudicate", and that dimension seems to be important to Justice Powell. ${ }^{51}$

But what of a state higher education commission or coordinating board, which nnight well make findings of past discrimmation in promulgating a special minority admissions or support program? Such agencies do not engage in adjudication, although they may occasionally hear appeals, for exaunple, from students demed "resident" status for tuition purposes. For that matter, the agencies mvolved in the cases Justice Powell cited-HEW in Lau v. Nichols ${ }^{52}$ and the Justice Departunent in United Jewish Organizations, Inc. v. Carey ${ }^{53}$-are not adjudicative agencies either. ${ }^{54}$ On the other hand, state higher education

51. See note 54 infra.

52. 414 U.S. 563 (1974).

53. 430 U.S. 144 (1977).

54. The importance of the adjudicative function is unclear. Neither HEW nor the Justice Department are primarily adjudicative bodies. Similarly, neither the federal nor the state departments of labor which made the administrative findings in the employment cases cited by Justice 
commissions and coordinating boards are likely to encompass the perspective of the entire state. It may make some difference to Justice Powell whether the officials of such bodies are elected or appointed, although both those elected directly and those appointed by an official who is accountable to the voters are likely to be quite sensitive to political pressures. Also, a state commission is less likely to be swayed by local pressures than a university governing board-while trustees at times have been locked up by dissident groups, state commissioners never have been. Members of such agencies possess expertise in higher education and would be likely to defer, as Justice Powell believes they should, to university admissions decisions. Finally, a state department would almost surely be subject to the procedural formalities of the state equivalent of the Admimistrative Procedures Act. In short, a strong case can be made that a formal finding of discrimination and of appropriate remedy made by a higher education agency or commission should be granted at least as mucl credit as an individual decree made by a state civil riglits commission.

This review of possible discrimination-finders eventually brings us back to the university governing board. Justice Powell observed that the University of California Regents had not purported to make appropriate findings, and that any attempt on their part to liave done so would have been legally ineffective. It is not clear whether Justice Powell appreciated the special constitutional status of the University of California Regents (held coequal to that of the legislature during the loyalty oath controversy ${ }^{55}$ ) or their sensitivity to political pressures (well illustrated by the dismissal of a President im 1967 ${ }^{56}$ ). Even if Justice Powell understood the actual stature of the Regents under California law, his decision need not be read as precluding approval of governing boards chosen in a different manner. There are three different models of trustees. The trustees can be an elected, constitutional body, as in Michigan. ${ }^{57}$ The trustees can be an appointed constitutional body, as in California. ${ }^{58}$ Or, the trustees can be an appointed, nonconstitutional body, as in Indiana. ${ }^{59}$ Justice Powell might defer to the findings of an elected constitutional body even thougli he did not

Powell are primarily adjudicative bodies. $98 \mathrm{~S}$. Ct. at 2754-55. Most the administrative agencies have had authority delegated to them to make findings of discriminatory practices, as HEW had under the Civil Rights Act of 1964, 42 U.S.C. $\$ 2000$ d-1 (1970), implemented in 45 C.F.R. $\$ 80.3-$ .10 (1977), and the Attorney General had under The Voting Rights Act of 1965, 42 U.S.C. $\$ 1783 \mathrm{c}$ (Supp. V 1975)? See also $98 \mathrm{~S}$. Ct. at $2755 \mathrm{n.41}$.

55. Cal. Const. art. IX, §9. See Tolman v. Underhill, 39 Cal. 2d 708, 249 P.2d 280 (1952). See generally O'Neil, Law and Higher Education in California, in Public Higher Education IN California 191 (1974).

56. Clark Kerr was dismissed in 1967. N.Y. Times, Jan. 21, 1967, at 2, col. 1.

57. Mich. Const. art. $8, \S 5$, implemented in Mich. COMP. LAws. ANN. $\$ 168.286$ (1967).

58. CAL. Const. art. $1 \mathrm{X}, \S 9$ (a).

59. IND. CODE ANN. $\S \S 20-12-1-1$ to 20-12-1-6 (Burns 1971). 
defer to an appointed constitutional body. Presumably, he would be least likely to defer to the findings of an appointed, nonconstitutional body.

\section{What Must Be Found?}

Even if we know what body may make the critical finding, we must also ask how explicit that judgment need be. A remedial judicial decree typically will recite past acts of discrimmation before entering an order. How broad a remedy will the acts underlying such a decree support? Justice Powell spoke at several points about "remedies deemed appropriate to rectify the discrimination" 60 and of a "classification responsive to the identified discrimination." 61 If the specific relief ordered is the admission of a single student-a Charlayne Hunter ${ }^{62}$ or a James Meredith, ${ }^{63}$ for example-to what extent will the findings later warrant inucl broader voluntary remediation? It seems unlikely that Justice Powell would preclude the Umiversity of Mississippi from fashioning a race-conscious program to help blacks generally on the basis of the findings in the Meredith case. ${ }^{64}$ A inuch more difficult question arises with regard to other minorities. To what extent can the Meredith findings sustain adinission preferences for ethnic groups-Latinos and American Indians, for example-who were not involved in the earlier cases?

There are several other variations on this problem. Sweatt $v$. Painter,${ }^{65}$ for example, undoubtedly validates past and present raceconscious admission policies of the Umversity of Texas Law School at Austim, the direct target of the decree. Since the segregation there apparently was the result of a state law, ${ }^{66}$ other units of the Austim campus (and other public colleges in Texas at that time) could also invoke that finding. But what of the Lyndon B. Johnson School of Public Affairs, founded long after the elimination of the historic Texas color bar? What of the Permian Basin Campus, which came into being at a time when Texas and the university systein were committed to integration, rather than segregation? Does it make sense to say that the law school inay forever give preference to minorities, while the LBJ School may never do so? Perhaps Justice Powell would grant that if the whole uni-

\footnotetext{
60. $98 \mathrm{~S}$. Ct. at 2754.

61. Id. at 2759.

62. Holmes v. Danner, 191 F. Supp. 394 (M.D. Ga. 1961).

63. Meredith v. Fair, 298 F.2d 696 (5th Cir.), ccrt. denied, 371 U.S. 828 (1962).

64. Id.

65. 339 U.S. 629 (1950).

66. Tex. Const., art. VII, $\S \S 7$, 14; Tex. Rev. Civ. Stat. ANN. art. 2643b, 2719, 2900 (Supp. 1949) (Vernon), cited in Sweatt v. Painter, 339 U.S. 629, 631 n.l (1950). See generally Jones, The Sweatt Case and the Development of Legal Education for Negroes in Texas, 47 TEXAS L. REv. 677
} (1969). 
versity or the entire state were once segregated in the way found against one branch or unit, then the whole university (including post segregation units like the LBJ School) inay take race into account to an extent reasonably necessary to eliminate the broader effects of the past discrimination. A narrower and nore literal reading of the Powell justification would produce perverse results and would make race-conscious policies difficult to administer. ${ }^{67}$

There are at least two other variations of this problem. One involves the state college that did in fact have a formal color bar-discoverable, for example, in bulletin language prior to the late 1950 's - but which was never even collaterally the subject of a court order. Due to recent litigation, ${ }^{68}$ many of the colleges in this category are now subject to an obligation to disinantle dual state systems. In the states affected by this litigation, ${ }^{69}$ the lack of an earlier and narrower decree should be immaterial.

The other variation pertams to once segregated private institutions and is more troublesome. Very few independent colleges and universities have been the subject of litigation to eliminate color bars. Simce Runyon v. $\mathrm{McCrary},{ }^{70}$ it is clear that the absence of direct tax support will not insulate the racially discriminatory admission policies of a private school or college. Relatively few such color bars remain today, and racially preferential policies are in fact extensive in the private sector. Should such programs be challenged, as they undoubtediy will be, courts presumably will ask whether earlier findings of discrimination in the public sector may also extend to the private sector. ${ }^{71}$ The Powell opinion does not remotely reach these issues.

The "findings" rehed on in the legislative context present similar problems as to the scope of their applicability. The typical preamble to a state equal opportunity program is general and unfocused. It may declare that certain groups have been denied the full benefits of the educational systein of the state and assert that such benefits are neces-

67. See O'Neil, Racial Preference and Higher Education: The Larger Context, 60 VA. L. REv. 925, 928-30 (1974).

68. Adams v. Richardson, 356 F. Supp. 92 (D.D.C. 1973), enforcing 351 F. Supp. 636 (D.D.C. 1972), modified and aff'd per curiam, 480 F.2d 1159 (D.C. Cir. 1973) (en banc), supplemental order sub nom. Adams v. Weinberger, 391 F. Supp. 269 (D.D.C. 1975), second supplemental order sub nom. Adams v. Califano, 430 F. Supp. 118 (D.D.C. 1977).

69. The decrees in the Adams suit, $i d$, cover only Arkansas, Florida, Georgia, Louisiana, Maryland, Mississippi, Pennsylvania, North Carolina, Oklahoma, and Virgimia, although comparable conditions exist in other states.

70. 427 U.S. 160 (1976).

71. There is, of course, a substantial question about the reach both of federal nondiscrimination obligations and of federal statutory remedies to private or independent institutions of higher learning. See, e.g., Stewart v. N.Y. Univ., 430 F. Supp. 1305 (S.D.N.Y. 1976) (declining to reach the merits of a challenge brought by a rejected white female applicant under Title VI against the racially preferential admissions program of a private university law school). 
sary to full participation in society. Such declarations technically fall short of the "findings of constitutional or statutory violation" that Justice Powell expects. Yet they do serve the purposes for which he invokes the requirement. A legislature that makes such a declaration and then authorizes a prograin to prefer minorities surely has made a conscious choice, clear on the public record and accountable to the political process, to favor one group to the possible detriment of others. It would seein overly mechanistic to demand that a legislature recite specific acts or occasions of discrimination in order to validate such prograins. Yet uncertainty reniains: Justice Powell may have his own reasons for demanding a kind of legislative "nostra culpa" and may refuse to honor the blander language of the typical legislative preanible. The argunients to be inade for accepting general statements of legislative purpose are compelling, but there is no guarantee that Justice Powell (or any meinber of the Stevens group) would find them sufficient.

The discussion of "eliminating the effects of discrimination" as a permissible goal for using race ends here. Some imsights into Justice Powell's reasons for finding such an objective to be a "compelling governmental interest" have been identified. We lack firm assurance, however, that anything beyond a clear judicial or administrative finding or express authorization from the United States Congress would validate a race-conscious prograni. Strong arguments exist for extending this basis of validation to other settings to which Justice Powell's rationale applies. As we move further from the clear and safe situations demarcated by the Powell opinion, however, the consequences become increasingly nore speculative.

\section{B. Promoting Diversity in the Student Body.}

Justice Powell offered another and quite distinct reason for taking race into account in the adinissions process: "the attainment of a diverse student body." $72 \mathrm{He}$ inight sinuply have stated that diversification was a "compelling interest" for its own sake, as some have argued. ${ }^{73}$ Instead, he took the less direct and obvious route of bringing the admissions process within the ambit of acadenic freedom. Thus, he gave the adinissions process independent first anendment stature. ${ }^{74}$ This

72. $98 \mathrm{~S} . \mathrm{Ct}$. at 2760 .

73. See, e.g., Griswold, Some Observations on the DeFunis Case, 75 Colum. L. REv. 412, 517-19 (1975).

74. $98 \mathrm{~S}$. Ct. at 2760 . This step was not wholly unprecedented. Justice Frankfurter two decades ago had found among the elements of academic freedom the opportunity of a university "to determine . . . who may be admitted to study." Sweezy v. New Hampshire, 354 U.S. 234, 263 (1957) (concurring opinion). The American Association of University Professors has Iong believed that the admissions process deserves protection along with the curriculum, the library, and the extracurricular expression of faculty members. Joint Statement on Rights and Freedoms of 
section will explore the compelling state interest of diversity. First, I will probe the definition of diversity. Then I will discuss the problem of measurement and conclude with some thoughts about the practical problems of achieving diversity and distinctions that can be drawn between diversity in undergraduate and graduate programs.

\section{How Can Diversity Be Defined?}

The term "diversity" surely is not a term of art, either in law or in higher education. Justice Powell rehed on the definitions offered by Princeton University, ${ }^{75}$ Harvard College, ${ }^{76}$ and a report prepared for the Carnegie Council on Policy Studies in Higher Education. ${ }^{77} \mathrm{He}$ emphasised diversity in student backgrounds-"whether it be ethnic, geographic, culturally advantaged or disadvantaged-[which] may brimg to a professional school . . . experiences, outlooks and ideas that enrich the training of its student body and better equip its graduates to render with understanding their total service to humanity." 78 This approach is partly descriptive and partly prescriptive. Justice Powell at times seems primarily concerned with what students have done, whence they have come, and what they have experienced. At other times, he focuses on what they may contribute to the life of the institution and the learning process of their fellow students. It is quite possible that persons with vastly varied backgrounds would contribute little to one another's college or graduate school experience. Conversely, the careful selection of students from rather homogeneous backgrounds could produce an extremely hively classroom and extracurricular experience. Yet even though there is no necessary connection between the two, the likehest prospect is that diversity in both background and outlook will create the "robust exchange of ideas" that Justice Powell believes colleges and universities may seek. ${ }^{79}$ But what if the expansion of ininority enrollments in previously all-white student bodies does not, in fact, brimg about this "robust exchange?" The constitutional relevance of data showing that ethnic diversity does not create such an exchange is unclear. Could a plaintiff such as Allan Bakke, in a later case, impeach an otherwise valid preferential admissions program by showing that no "robust exchange" in fact occurred? Should courts heed evidence that

Students, in American Association of University Professors, AAUP Policy Documents AND Reports 53 (1977). See also T. EMERSON, The SyStem of Freedom of EXPREsSion 596 (1970).

75. 98 S. Ct. at 2762 n.51.

76. Id. at $2762,2764-66$ (appendix).

77. Id. at 2761 n.50.

78. Id. at 2761.

79. See, e.g., the rather disparaging account of the effects of racial integration in a recent survey of conditions on predominantly white campuses, Middleton \& Sievert, The Uneasy Undercurrent, Chronicle of Higher Educ., May 15, 1978, at 1, col. 2. 
minority students often tend to study, eat, and live by themselves, and that white students do likewise, so that significant imformal contact does not always occur?

At least three answers suggest that such evidence should not undercut a good faith goal of "diversification." First, racial isolation im historically segregated institutions is most often a transitional phenomenon-to be expected during the early stages of integration, but likely to lessen as time goes on and as trust builds across racial lines. ${ }^{80}$ Second, the inere presence of students of different races and ethnic backgrounds in the student body and in the classrooin goes far to advance the very interests that Justice Powell stressed, even if hittle informal contact occurs. White students will at least be exposed to the views and experiences of their minority classmates in the classroom-the settimg to whicl tlie first amendment inost clearly applies in higher education. Third, it nay well be that Justice Powell ineant to state a conclusion of law rather than of fact. Much as the Supreme Court declared in Brown v. Board of Education ${ }^{81}$ that segregation of the public schools impaired the learning of black children and then refused to hear contrary evidence, ${ }^{82}$ perhaps Justice Powell would not consider any factual allegations contrary to his conclusion. Thus, proof that minority and majority students ate at different tables in the cafeteria and did not talk inuch in the corridors between classes would be legally irrelevant, even if factually valid.

\section{How Can Diversity Be Measured?}

Justice Powell did not say inucl about the measurement of diversity, beyond commending Harvard for its flexible approach. ${ }^{83}$ Many institutions have set goals for minority enrollments that approximate the minority share of the general population. Such targets, even if they do not (like the Davis prograin) involve precise or fixed numbers, may now be suspect. Justice Powell inight well say that such a set minority

80. There is some indication that when minority enrollments reach a "critical mass" within the formerly white institutions, the process of assimilation may extend beyond the formal classroom setting. Pressure for special racially separate dormitories, for example, diminished sharply after the late 1960's, and minority students largely have been absorbed into the general residential structure at most institutions. See McPherson, The Black Law Student: A Problem of Fidelities, Atlantic Monthly, Apr. 1970, at 98.

81. 347 U.S. 483 (1954).

82. See, eg., Stell v. Savannah-Chatham Co. Bd. of Educ. 220 F. Supp. 667 (S.D. Ga. 1963), rev'd, 333 F.2d 55 (5th Cir.), cert. denied, 379 U.S. 933 (1964) (disapproved on other grounds, Davis v. East Baton Rouge Parish School Bd., 380 F.2d 385, 389 n.3 (5th Cir.) (en banc) (per curiam), cert. denied, 389 U.S. 840 (1967)).

83. Curiously, Justice Powell omitted from the portion of the Harvard statement that he quoted in the text of his opinion, $98 \mathrm{~S}$. Ct. at 2762 , the following sentence, which bears significantly on the issue of numerical objectives: "At the same time the committee is aware that if Harvard College is to provide a truly heterogeneous environment that reflects the rich diversity of the United States, it cannot be provided without some attention to numbers." Id. at 2765. 
share reveals the forbidden "purpose to assure within [the] student body some specified percentage of a particular group merely because of its race or ethnic origin . . ."84 Even the Brennan group might fault such an approach, for they noted with approval that Davis had not set its goal at the minority proportions of the California population, twenty-three percent, but at the lower figure of sixteen percent. ${ }^{85}$ Two preliminary cautions einerge. First, a general range of minority representation, or perhaps even a presumptive minimum, is unore likely to show a genuine quest for flexibility than a target percentage tied strictly to the demography of the state or region. Second, if diversity is the paramount goal, the resulting minority enrollments probably should vary from year to year. The maintenance of a perfectly uniform figure fron 1 class to class would be highly suspect, and might well jeopardize the inference of bona fides.

At least one other measurement issue deserves some mention here. While many colleges are confined in their quest for diversity by the nature of the applicant pool, ${ }^{86}$ others may limit their own discretion as a matter of choice. Some church related colleges and universities, for example, prefer students of a particular faitl. Such a focus drastically limits the diversity of the student body in several ways. Mormons, Christian Scientists, and members of other faiths tend to be socioeconomically, politically, and even geographically homogeneous. Thus, an attempt on the part of such schools to achieve student diversity may turn out to be unidimensional-it may focus solely on race or ethnic group meinbership. Has Justice Powell said that such an institution, in order to invoke his principle of diversity, must seek a different mix in other respects as well? It is one thing to say that a state college whose applicant pool is lomogeneous by default may focus on race alone; ${ }^{87}$ but that conclusion is less clear for a private institution that has voluntarily limited the breadth of its applicant pool and then seeks to invoke race as the sole diversifying factor.

Sucli a unidimensional emphasis might be valid, lowever. First, an mstitution might be able to show that the natural selection process would generate sufficient diversity on all relevant grounds which its selection system ignores without any conscious efforts. Even random selection froin a diverse applicant pool often yields a student body of varied religious, geographic, and work experience backgrounds. Second, it might be shown that efforts to diversify along other lines would be ineffectual-for example, an institution in rural Arkansas might be unable to attract students with urban backgrounds or students from the

84. Id. at 2757.

85. Id. at 2792 n.58.

86. See text accompanying notes 67-69 infra.

87. Id. 
far West. Finally, a court might be persuaded by proof that diversification along lines other than race would compromise the basic character of the institution. A fundamentalist church school, for example, could not easonably be expected to seek out Catholics, Jews, or perhaps even persons from urban areas, but might still seek rural blacks whose religious views would be compatible. Any of these three justifications for a unidimensional race-conscious admissions policy might satisfy Justice Powell, although we do not yet know the full scope of his views on the issue.

\section{How Can Diversity Be Advanced?}

This is not the place to analyze specific admissions plans in detail, or to appraise the legality of rcal or hypothetical programs. A few general comments must suffice. Certain practices closely resembling the Davis plan-the operation of a wholly separate minority admissions committee: the reservation of a separate number of slots for minority applicants (whether carved out from the regular class or appended to it); or the use of a constant and arbitrary number-surely are suspect. At the other extreme, approaches consistent with the Harvard policy-giving individual consideration to the records of all qualified applicants; using race as the "plus" which tips the final choice in favor of the minority applicant; and considering nonminority applicants who exhibit similarly "diverse" quahties and backgrounds-undoubtedly would fare better. Obviously there is much latitude for an institution to design an adınissions program directed toward achieving diversity.

The enshrineinent of the Harvard College admissions policy in Justice Powell's Bakke opinion may prematurely truncate creative efforts to achieve diversity. Institutions that seek a safe and tested raceconscious admissions plan may uncritically copy the Harvard policy im the belief that at least five votes would be assured should it become the subject of a Supreine Court test. Apart from the issue of whether Harvard College in fact follows its policy statement, ${ }^{88}$ the applicability of this approach is severely limited. Very few institutions, at least at the undergraduate level, enjoy anytling approaching the scope of choice that Harvard lias long had in selecting its freshmen class. Even relatively selective colleges cannot regularly choose among oboists from Montana, soccer players from Florida, and straight " $\mathrm{A}$ " students from Maine. Their judgments are himited by various forces from which Harvard is alınost uniquely free. For example, public institutions are largely restricted to residents of the state, either by externally imposed geographical quotas or sinply by the practical effect of rising tuition differentials. Private institutions, too, tend to draw from the surround-

88. See, e.g., Dershowitz, Powell's Beau Idéal, The New Republic, July 22, 1978, at 14. 
ing region, save for a very small number which have truly national clienteles. ${ }^{89}$ Thus "diversity" for the vast majority of colleges, and even many graduate programs, means drawing the best from a remarkably homogeneous pool. The ricl array of choices that excite the Harvard admissions officers, and their counterparts at Stanford, Princeton, and a few other highly selective scliools simply does not exist elsewhere. Thus the extent to which the Harvard policy can be generalized is quite limited, and the security it seems to offer is somewhat illusory.

In shaping a legally acceptable admissions policy that will fall within the two extremes exemplified by Harvard and Davis, a threshold question must be faced: which groups may be preferred? Justice Powell's opinion contains no answer, simce "diversity" is for him a rationale wholly distinct from eliminating the effects of discrimination. Thus Justice Powell presumably would allow an institution to favor members of minority groups that had not been past victims of even societal discrimination (nuch less discrimination by the institution itself). At that point, however, one would risk losing members of the Brennan group for whoin some proof of actual discrimination is necessary. Moreover, the Brennan group Justices would seek evidence that contimuing the institution's past policies would perpetuate the disadvantage, and that the preferential program would impose no stigma. One can imagine a program designed to imclude Koreans, Vietnamese, Polynesians, or perhaps Cubans which might meet Powell's notion of "diversity," but which would not necessarily pass the Brennan group's test. One who seeks to fashion an acceptable plan must bear in mind that "diversity" claims only one vote, and that different factors appeal to the balance of the Court. The actual process of taking race into account in adinissions is an exceedingly complex one. Any race conscious system must be adapted to its particular admissions situation. The range of such situations may be presented as a matrix of at least two dimensions. Along one axis should be arrayed the stages in the admissions process, from the initial announcement of educational opportunities through the drafting of the application blank, the initial screening of the applications, the first selection, the final allocation of spaces, the awarding of credit for prior educational or other experience, and the awarding of financial aid. Along the other axis would appear the many possible ways in which race might be taken into account-adjustment of standardized test scores or predicted first-year averages; giving points or a "handicap" for belonging to certain racial or ethnic groups; waiving certain prerequisites; "rescuing" minority applicants from automatic rejection early in the process, and so on. It is also possible to recognize minority status indirectly through a definition of "disadvantagement"

89. See C. Jencks \& D. Riesman, The Academic Revolution 286-90 (1969). 
that may be more or less minority-specific in results despite seemingly neutral terminology. ${ }^{90}$ The full matrix may have dozens of boxes, in any one of which an admissions process plausibly could be placed.

Most institutions probably will wish to use an approach subtler than that of Davis but simpler than that of Harvard. ${ }^{91}$ Only through further litigation will answers emerge more clearly. The Supreme Court has provided the general framework, and the lower courts must now begin to fill in the matrix.

\section{Graduate vs. Undergraduate Admissions}

One further facet of the diversity issue merits attention. Justice Powell suggested that "there is greater force to these views at the undergraduate level than in a medical school where the training is centered primarily on professional competency."92 Since the most critical challenges to race-conscious admissions have arisen and will probably contimue at the graduate level, this comment is obviously important. Justice Powell offers a partial explanation-recalling the discussion in Sweatt $v$. Painter ${ }^{93}$ about the importance of diversity in legal education, noting that "physicians serve a heterogeneous population," 94 and quoting the President of Princeton University on the comparability of goals in selecting the most promising students for both graduate and undergraduate programs. ${ }^{95}$ Yet one might still fear that Powell's notion of diversity is most applicable at the undergraduate level-if only because the discussion of the Harvard policy is so clearly concerned with baccalaureate education. Consequently, institutions that seek to justify raceconscious policies at the graduate level should be mindful of the possible distinctions between graduate and undergraduate programs.

Admissions to graduate programs in the arts and sciences pose an issue quite different from that of admissions to professional schools. ${ }^{96}$ Even for the largest and most popular doctoral programs, the number of applications eacli year is manageable enough to permit each file to be considered carefully and individually by a faculty member or by the full admissions committee of the department. The final decisions can be made on individualized grounds; seldom do they reflect the kind of

90. See, e.g., Quantifying "Disadvantagement”, in After Bakke: Working Papers Prepared for the Post-Bakke Planning Conference, New York, June 1-2, 1978, tab C (mimeo).

91. For an example of a pre-Bakke decision sustaining a minority race conscious admission policy on grounds more flexible than those of the California Supreme Court, see Rosenstock v. Board of Governors, 423 F. Supp. 1321, 1325-26 (M.D.N.C. 1976).

92. $98 \mathrm{~S}$. Ct. at 2761.

93. 339 U.S. 629,634 (1950).

94. $98 \mathrm{~S}$. Ct. at 2761.

95. Id. at 2761 n. 49 .

96. See generally National Board on Graduate Education, Minority Group l'arTICIPATION IN GRADUATE EDUCATION (1976). 
numerical ranking of grades and standardized test scores that many graduate professional schools rely on by choice or by necessity. The typical admission process for doctoral programs meets Justice Powell's canons since applicants are individually reviewed and a multiplicity of factors are considered. Moreover, a rejected applicant would have great difficulty proving that he or she would have been admitted but for a minority preference ${ }^{97}$ since even members of the admissions committee may disagree widely on the ranking of candidates below the actual cutoff poimt. Most graduate arts and sciences faculties, to the extent they take race into account at all, are probably already doing much of what Justice Powell admired about the Harvard approach, and should have less to fear than do those admmistering undergraduate and professional programs.

In ending this cursory section on diversity, it is useful to restate a point made earlier and somewhat obliquely. The problems with which we have been concerned here-for example, the apparent need to seek diversity on dimensions other than race-arise only when the stated goal of a minority program is diversity. The institution that seeks any of the other goals-eliminating the effects of discrimination, or meetimg the needs of underserved areas-may disregard these concerns, since Justice Powell considered these goals to be independent. If there is a judicial finding of past segregation, ethnic diversity may still be sought for educational policy reasons, although they would be constitutionally superfluous. Conversely, a quest for diversity removes the need for any findings of past discrimination. At this point, however, the relationship between the Brennan group and Powell opmions becomes crucial. Not all diversification which would satisfy Powell would clearly satisfy the Brennan group. There are two masters to be served, and while they concur at many pomts they are not in complete accord.

\section{IV}

\section{RaCe AND Financial AID}

None of the Bakke opinions addressed the question of financial aid, nor would it have been appropriate for the Court to have done so. Yet in the practical realm of higher education policy, the reassessment of admissions policies will require some attention to financial aid policies as well. It may be useful to offer some preliminary thoughts on the extent to which Bakke may affect these pohicies.

Race-conscious admissions and financial aid are of course closely and critically related. Minority students often have unusually heavy

97. Cf. Alevy v. Downstate Medical Center, 39 N.Y.2d 326, 348 N.E.2d 537, 384 N.Y.S.2d 82 (1976) (applicant to medical school failed to show that he would have been admitted but for minority program). 
financial burdens and needs. ${ }^{98}$ For many minority youths, admission to college or to graduate school is meaningless without assurance of substantial aid. To ineet the needs of minority students, many colleges and universities have created special programs, either by setting aside major shares of their own funds, or by seeking external support earmarked for this purpose. The legality of such policies has been a subject of debate for some time, and the intensity of discussion is not likely to be allayed by the Bakke decision.

Before turning to specific situations, we should note briefly the difference between admission and financial aid. Bakke and most of the other preferential policy cases have been concerned with a benefit or opportunity of very substantial value-admission to a selective and desirable acadenic program. Even where the applicant is willing to bear a inajor share of the educational costs, the value of admission per se is beyond dispute. At the other end of the benefit spectrum, it seems unlikely that a court would seriously entertain a challenge to a small book prize offered to the outstanding minority student in each class. Some disputes over government benefits are trivial and will be treated as de minimis, while others may be avoided because the allocation is discretionary. The grant or denial of financial aid falls somewhere between the admission decision and the book prize. There have been relatively few financial aid cases, though several courts have treated scholarships and fellowships as substantial benefits. ${ }^{99}$ Disputes over financial aid therefore would seein to be justiciable, and it is with such issues that we shall be concerned here.

\section{A. Federal Programs}

Within the past decade a nuinber of federal programs have been created for the purpose of aiding minority students at various levels of higher education. ${ }^{100}$ Since these programs require explicit authorization and funding by Congress, there should now be little doubt about their validity. Sucl programs sliould satisfy Justice Powell. Nor should they be subject to the statutory objections voiced by the Stevens group in Bakke, since Congress has the power to modify the ban that the Stevens group found in Title VI. ${ }^{101}$ Of course, any inember of the Stevens group could find a constitutional violation in such a program once the constitutional ground was reached. Undoubtedly the Brennan group would uphold such a program, unless they found it to be either stiginatizing or unrelated to a disadvantage that would persist without

98. See F. Crossland, Minority Access to College 64-66 (1971).

99. E.g., Flanagan v. President and Directors of Georgetown College, 417 F. Supp. 377 (D.D.C. 1976).

100. See, e.g., 20 U.S.C. § 1134r-1 (Supp. 1975).

101. $98 \mathrm{~S}$. Ct. at $2809-15$. 
such aid. Given the clearly demonstrated financial needs of minority students, the relationship between problem and remedy required to satisfy the Brennan group should not be hard to find. Thus federal financial aid programs should have the blessing of a clear majority of the Supreme Court, and might even gain unanimous approval.

\section{B. State Legislative Programs}

The second case is that of an mstitution that administers a similar grant with funds earmarked for minority students by a state legislature. We have no idea what the Stevens group would say about such a prograin, since they spoke only of the federal statutory constraint. We can assume that the Brennan group would accept such a program as readily as they would sustam federal grants for minority fellowships. The problem here, as on so many issues, lies in anticipating Justice Powell's views. Justice Powell did imply that a state legislature could make the sort of judgment that he would not allow the University of California Regents to make--partly because a university board may not understand or reflect all of the elements that should influence such a sensitive decision and partly because it might be tempted to make a short range or even expedient decision in favor of one group without assessing the impact on others. If elected state legislators, fully accountable to the citizens, make such a decision and are aware of the consequences, even a fellowship program that exclusively aids mimority applicants may be vahid.

\section{State Administrative Programs}

Apart from explicit state legislation, a state higher education agency or scholarship commission might well allocate funds for a special minority aid program. Here too, of course, Justice Powell's views are crucial. He included "administrative agencies," along with courts and legislatures, in the group of valid decisionmakers. He was presumably thinking, however, of a state antidiscrimination or human rights cominission, which could make findings of past discrimination that could support responsive remedies by the state's institutions of higher learning. The role of the higher education agency is far less clear. In some states, such agencies or commissions do have fellowship funds that might well be used in this way. Such an agency would, like the University of California Regents, be concerned primarily with education rather than with discrimination, and that focus would cause its actions to lose some legitimacy in Justice Powell's eyes. On the other hand, such agencies do make findings that are publicly accessible and reviewable, and they are usually sensitive to the political process, through election or appointment. The chance of getting Justice Powell's vote on this alternative is therefore unclear, though a persuasive 
argument can still be made for such a program under Justice Powell's criteria.

\section{Allocation of Institutional Funds}

Either a state-supported institution or a private institution subject to Title VI might well be challenged for setting aside a portion of its own financial aid funds for minority students. Two such cases have already gone through the lower courts and have reached conclusions consistent with the distinctions drawn im Bakke. In one case, the initial reservation of sixty percent of all scholarship funds for mimority students comprising eleven percent of the class, to be awarded without regard to relative needs of inmority and nonminority applicants, was found to violate Title VI through reasoning that largely anticipated Bakke. ${ }^{102}$ The other case involved a more flexible policy that did not disregard relative financial needs; the court dismissed the complaimt because a white plaimtiff could not show that lie would have received more aid if no funds had been set aside for minorities. ${ }^{103}$

In future cases, the courts presumably will apply the same kind of reasoning to otler scholarship cases that Bakke apphes to admissions policies. Both the goals of the prograin and the inethod of meeting the goals are likely to be reviewed with care. A commitment either to eliminate the effects of past discrimmation or to achieve diversity im the student body would be persuasive. Flexibility in the procedures for determining relative needs among all applicants would also help, even if race were expressly entered in the allocation formula. Given the generally greater financial needs of minority students, nonracial criteria of disadvantage may well be more useful for financial aid than for adinissions decisions. Finally, as the second of the two decided scholarship cases suggests, the white apphicant who is denied aid or who receives less aid than he would have liked can nuch less readily trace his grievance to a racial preference than can the person rejected outright for admission to a selective program. Reasonable care in the frammg of financial aid policies should therefore ninimize the risks, whether or not the Bakke analysis is wholly apposite.

\section{E. Administration of External Funds Restricted to Minorities}

The most difficult problem is that posed by the college or university that accepts and awards a restrictive scholarship-a perennially troublesome issue whose origins long antedate the current contro-

102. Flanagan v. President and Directors of Georgetown College, 417 F. Supp. 377 (D.D.C. 1976).

103. Mosier v. University of San Francisco, No. 77-0075 (N.D. Cal. 1977). 
versy. ${ }^{104}$ Presumably a college or university incurs no legal risk in admitting a student who is supported by racially restrictive funds from a completely external entity. The problem arises only when the institution becomes the vehicle through which racially selective views of a donor may be implemented. Historically the issue has been encountered most often with grants or bequests confined to whites or to males, and the constitutionality of administering such funds has never been firmly settled. Supreme Court decisions on related questions-administering a park given to a city on condition that it be kept segregated, ${ }^{105}$ governmental appointment of trustees for succession to the trusteeship of a segregated school, ${ }^{106}$ and the closing of municipal swimming pools to avoid a dcsegregation decree ${ }^{107}$ - offer some guidance but have left the precise resolution of the issue a matter of speculation.

The case of the preferential or minority-favoring fellowship might be distinguished from the cases that already have been the subject of Supreme Court review in several respects. First, achievement of the legitimate goals of race-conscious admissions programs surely would be enhanced by such external funding and may indeed require it where institutional funds are insufficient. Second, where such goals exist and are being served in good faith, it would be perverse to allow the institution to favor minorities in the allocation of its own funds, but disable it from using external funds for the same purpose. Third, such fellowships often supplement federal and state grants for minority programs, and could be vahidated by their proximity to the governmental programs that they reinforce. Finally, relevant governmental policies appear to condone such grants. The Internal Revenue Service has ruled that "scholarships and loans that are made pursuant to financial assistance programs favoring unembers of one or more racial minority groups that are designed to promote a school's racially nondiscriminatory policy will not adversely affcct the school's exempt status."108 Regulations of the Departinent of Health, Education, and Welfare under Title $\mathrm{IX}^{109}$ and under legislation protecting the handicapped ${ }^{110}$ are consistent with this IRS policy.

While the answer is not yet clear, and the courts have not spoken at all on the preferential fellowship issue, nothing in Bakke seems to deny colleges and universities the authority to administer such grants. Indeed, to the extent that Justice Powell's recognition of two familiar

104. See Note, Constitutionality of Restricted Scholarships, 33 N.Y.U. L. REv. 604 (1958).

105. Evans v. Newton, 382 U.S. 296 (1966).

106. Pennsylvania v. Board of Directors of City Trusts, 353 U.S. 230 (1957).

107. Palmer v. Thompson, 403 U.S. 217 (1971).

108. Rev. Proc. $75-50, \S 4.051975-2$ C.B. 589.

109. 45 C.F.R. $\S 86$ (1977).

110. 45 C.F.R. $\$ 84$ (1977). 
goals of such programs may reinforce the already favorable view of the Brennan group, Bakke may have done more good in this respect than harm.

\section{CONCLUSION}

From a legal perspective, Bakke was hardly an ideal test case. The admission program challenged in the DeFunis case was far more representative of professional school practices than the two-track system adopted by the Davis medical school. A totally cohesive Supreme Court judgment on the merits of Bakke would have left many questions unanswered. The actual fragmentation of the Court, with a majority supporting only the final disposition, compounded the ambiguity surrounding the role of race in higher education. The curious division of the Court gave an extraordinary prominence to the views of a single Justice which-unlike those of two of his colleagues-cominanded no further support within the Court. This extraordinary quality of the case also presented some of the Justices with an opportunity to express views that are broadly useful to the higher education community. The fact that the Harvard undergraduate admission pohcy was not before the Court, and that it drew the encomium of only one Justice, invites enlightened experimentation and allows room for inaneuvering in future cases. Surely we are not locked into any smgle admission policy or program. What is so unsatisfactory about the case to constitutional scholars may therefore be its greatest redemption for university administrators, foundations, and other higher education pohcymakers. When a more conventional admission case does come along, as it surely will soon, we will all be better prepared as a result of this preliminary skirmish. ${ }^{11}$

111. For an early and remarkably perceptive and thoughtful assessment of the import of Bakke, see A. SindLer, BAKKe, DeFunis, AND MinORITY AdMissions (1978), especially the concluding chapter, which looks beyond the Supreme Court decision. 